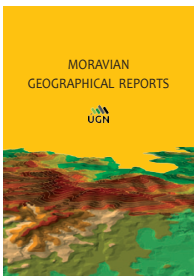

MORAVIAN GEOGRAPHICAL REPORTS

Institute of Geonics, The Czech Academy of Sciences

journal homepage: http://www.geonika.cz/mgr.html

doi: 10.2478/mgr-2019-0016

\title{
The fate of socialist agricultural premises: To agricultural 'brownfields' and back again?
}

\author{
Josef NAVRÁTIL ${ }^{\text {a }}$, Stanislav MARTINÁT a , Tomáš KREJČÍ a ${ }^{\text {, }}$ Kamil PÍCHA ${ }^{\text {a }}$, \\ Petr KLUSÁČEK a , Jaroslav ŠKRABAL a , Robert OSMAN ${ }^{\text {a }}$
}

\begin{abstract}
The variety of post-socialist agricultural transitions in four different rural regions located in South Bohemia (Czech Republic), with respect to the utilisation of the older premises, is subject to analysis in this article. A complete database was constructed, containing the identification of agricultural premises in 1989 and their use in 2004 and 2017. From 1989 to 2004, a number of agricultural brownfields emerged, and many sites had been utilised for non-agricultural purposes. After 2004, the acreage of agricultural brownfields was reduced and new land-use utilisation for housing and, especially other non-agricultural activities, significantly increased. The transition in the utilisation of pre-1989 agricultural premises is strongly influenced by the social and economic contexts in which particular sites are located. Proximity to an upperlevel regional centre is of crucial importance for decisions with respect to how (and if) the site will be reused. The peripheral location of the site also affects the level and the selection of options for the ways in which particular pre-1989 agricultural premises are used. In the case studies reported here, the marginality of particular regions is increased by their location in the border regions of outer peripheries, where the probability of the presence of agricultural brownfields and the probability of long-term abandonment of agricultural premises is higher. For the traditional developed countryside, we found a typical low level of the share of long-term agricultural brownfields. After 2004, the re-use of pre-1989 agricultural brownfields for agriculture was ascertained, which is complemented by their use for housing.
\end{abstract}

Keywords: agricultural brownfields, transitional economies post-socialism, reuse, abandonment, South Bohemia, Czech Republic, Central and Eastern Europe

Article history: Received 1 August 2019, Accepted 8 November 2019, Published 31 December 2019

\section{Introduction}

Although the agriculture sector in the former Czechoslovakia was one of the most productive agricultural sectors in Central and Eastern European countries (CEE) during the 1980s (Bański, 2008), it was not able to compete with the production levels of the Western European agricultural production systems (Doucha and Divila, 2008) after the fall of the Iron Curtain in 1989. As a result, the agricultural sector of Czechoslovakia started to diminish but food consumption remained more or less the same, and a significant part of food consumption was covered by imports (Zagata, 2012). When the Czech Republic became a member of the EU in 2004, the Common Agricultural Policy was applied; however, tendencies to a reduction in the agricultural production system have persisted.

All of these changes significantly affected the Czech agricultural sector. Therefore, some reasons to widen our understanding of these changes in the countryside are required. As the Czech agricultural sector is weakening in the last decades, many abandoned or under-used agricultural premises are found. In order to comprehend what has happened to these premises since 1989, our research comprises a special interest in the variety of re-uses that have occurred in rural areas situated in different sociocultural conditions.

\section{Conceptual background and hypotheses}

Until the beginning of 1990s, the "whole" life of rural settlements in the former Czechoslovakia had been closely linked to collective farms or the state farms that emerged in the 1950s during the process of collectivisation of agricultural land, with properties that were managed by the newly-established communist regime to take economic control over the agricultural sector and the countryside

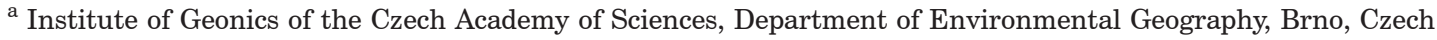
Republic (*corresponding author: J. Navrátil, e-mail: josefnav@gmail.com)
} 
(Lindbloom, 2012). Collectivisation had resulted in the establishment of very large collective agricultural farms, that were incomparably larger than any other in the EU (with the exception of Slovakia), and made possible their industrialisation. Collective farming begun in the $1950 \mathrm{~s}$ with the construction of large-scale premises such as cowsheds, intensive pig farms, intensive poultry farms, and operational buildings such as agricultural warehouses, machinery garages, stock houses, shop floors and office buildings (Svobodová and Věžník, 2009). Collectivisation completely changed the social dimensions of rural life and the premises of collective farms became not only a new physical dominant of Czechoslovakian villages, but also the new centres of rural settlements. Experiments in Czechoslovakian agricultural policy continued into the $1970 \mathrm{~s}$, when these farms were merged into even larger agricultural complexes, usually joined with facilities of small-scale industrial production.

The changes in the agricultural production system, after 1989 (with the market economy transition) and after 2004 (with EU membership), significantly affected the use of these earlier premises (Klusáček et al., 2013). While the transitions of the agricultural production systems after 1989 have already been studied intensively (Bičík and Jančák, 2005; Illner and Andrle, 1994; Jančák and Götz, 1997; Věžník and Bartošová, 2004), the changes to the utilisation of pre-1989 agricultural premises have not been of interest to researchers. Nevertheless, previous studies unequivocally show that the change of utilisation of these premises is important for a profound comprehension of the agricultural sector transition and for its effects, not only on agriculture but also on rural space (CzechInvest, 2008; Klusáček et al., 2013; Skála et al., 2013; Svobodová and Věžník, 2009).

In order to meet our main research objective, we identify agricultural transitions using the case of the present utilisation of pre-1989 agricultural premises in various types of countryside. South Bohemia was selected as a case study region representing various types of rural spaces. Hence, the type of rural space in selected areas of south Bohemia, is the leading factor for testing the changes in utilisation of pre-1989 agricultural premises between 1989 and 2017. In addition, we also researched areas bordering on pre-1989 agricultural premises that were not agricultural premises in 1989 but were such in 2004 and/or in 2017. In other words, we also focused on the expansion (or change) process of pre1989 agricultural premises.

We have chosen two time periods: the first period is from 1989 (when the Iron Curtain fell and the transition was about to begin) to 2004 (when the Czech Republic became a member of the European Union): the second period from 2004 to 2017 takes in consideration the effects of the Common Agricultural Policy of the EU on the utilisation of pre-1989 agricultural premises. The pre-1989 agricultural premises are defined here as buildings and their intensively managed adjacent sites that were used by cooperative farms or state farms for agricultural purposes up to 1989.

The following seven statistical hypotheses will be tested:

- Hypothesis 1: We assume that the areas of pre-1989 agricultural premises differ among regions depending on the structure and intensity of agricultural activities, with respect to varying geographical conditions (e.g. Jančák and Götz, 1997).

Although agriculture is a rather "traditional" economic sector, it depends on market fluctuation dynamics (Bonfiglio et al., 2017). These changes might be theoretically expressed not only by a change in utilisation of the pre1989 agricultural premises to 2004 or to 2017 , but also by their demolition or spatial development outside the former area (Klusáček et al., 2013). So, we will focus also on development outside the areas' borders. To date, there is a lack of studies dedicated to this issue. Nevertheless, from our field research, we learned that expansions of pre1989 agricultural premises are rare. Subvention schemes (Hrabák and Konečný, 2018), such as financial support, however, led to the growth of biogas plants and composting plants (Van der Horst et al., 2018) enlarging some of the pre1989 agricultural premises, even though there is a general decline in agricultural activities (Bičík and Jančák, 2005).

- Hypothesis 2: The level of the spatial expansion of pre1989 agricultural premises differs among individual regions and studied periods.

Changes in the utilisation of pre-1989 agricultural premises is more common than spatial expansion (Klusáček et al., 2013; Věžník et al., 2013). It was shown that those changes in utilisation are related to changes in the agricultural sector (Hrabák and Konečný, 2018).

- Hypothesis 3: The spatial extent of the studied types of new utilisation of pre-1989 agricultural premises differs between 2017 and 2004.

- Hypothesis 4: The spatial extent of the studied types of new utilisation of pre-1989 agricultural premises in 2004 as well as in 2017 differs among studied regions.

- Hypothesis 5: Change in the spatial extent of the studied types of new utilisation of pre-1989 agricultural premises from 2004 to 2017 differs among studied regions.

Regarding the life of rural communities, abandonment of agricultural premises and their following decline, presents probably the most substantial change leading to the abundance of typical agricultural brownfields (Klusáček et al., 2013; Skála et al., 2013). Agricultural brownfields are defined for our purposes as buildings and their intensively managed adjacent sites that had up to 1989 utilisation for agriculture and after 1989 were abandoned, i.e. without any use (Martinát et al., 2017). It is enormously difficult to find new uses for such sites that are not so attractively located (Frantál et al., 2015). Based on the above-mentioned ideas, there are two following hypotheses:

- Hypothesis 6: The regeneration of agricultural brownfields and their new uses differs for the period 2004-2017 among individual studied regions; and

- Hypothesis 7: The abundance of new agricultural brownfields after 2004 differs among individual studied regions.

\section{Study area}

The South Bohemian Region of the Czech Republic borders Austria and Germany (Popjaková and Blažek, 2015). The peripherality of the region is based on its history and the specifics of its economy. South Bohemia has always been known as one of the agricultural regions with a low population density and with a dominant number of small communities (70\% of the communities in South Bohemia have less than 500 inhabitants), and with an above average percentage share of inhabitants employed in agriculture (see Fig. 1).

The South Bohemian Region has been selected for our analysis as it consists of a variety of countryside types (Perlín et al., 2010), thus, providing good opportunities to 


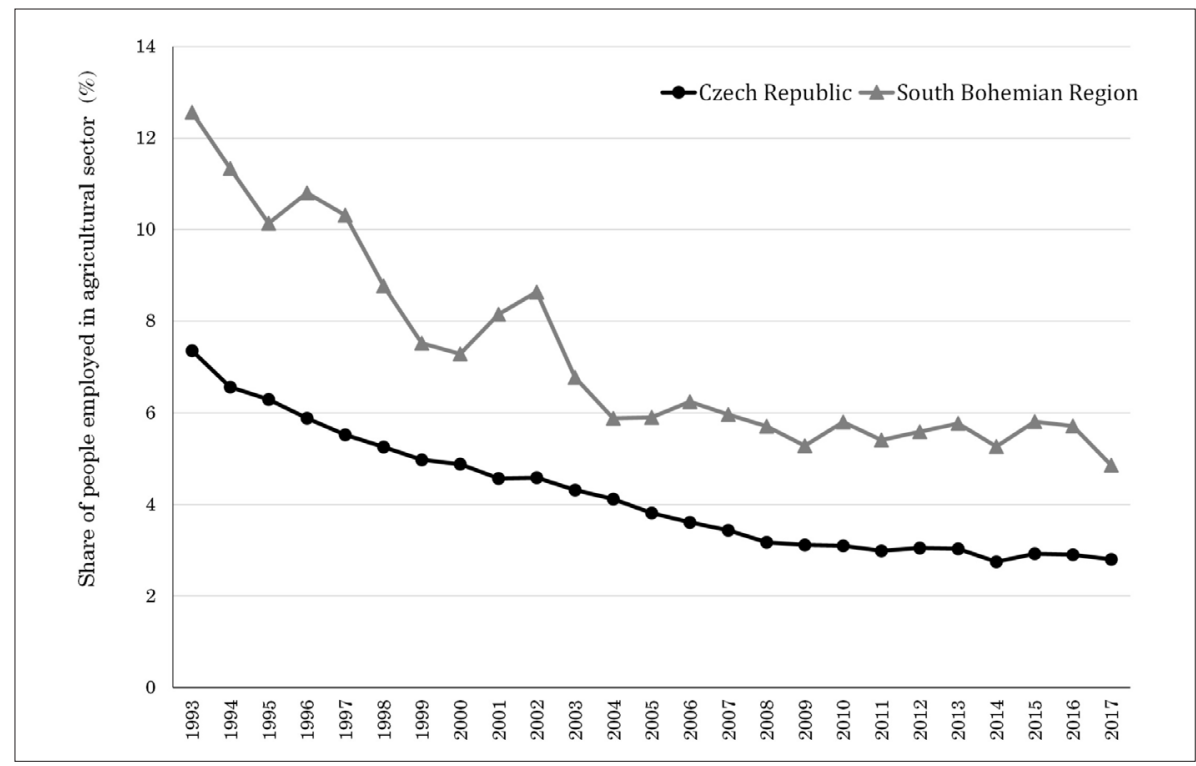

Fig. 1: Percentage share of people employed in the agricultural sector between 1993 and 2017 Source of data: Czech Statistical Office (2018); authors' elaboration.

compare the different trajectories of the development of pre-1989 agricultural premises. For this study, the areas of municipalities with extended powers called small districts (further, SDs) were selected. These districts were chosen as the spatial units closest to the "real" spatial organisation units of the Czech Republic (Klapka et al., 2016).

The SDs selected for the analyses had to meet the following criteria: they had to be located (1) in different districts; (2) not sharing a border with any other area under study; and (3) represent all types of countryside that have been detected in South Bohemia by Perlín and colleagues (2010). Using these criteria, the following four SDs were selected: České Budějovice, Blatná, Dačice, and Vimperk (Fig. 2).

České Budějovice SD is characterised as a 'developed' countryside (Perlín et al., 2010) surrounding the capital city of the South Bohemian Region - Ceské Budějovice (Budweis). In the area of Ceské Budějovice SD, no municipality is classified as peripheral according Kubeš and Kraft (2011). Blatná SD is a model region of the 'developing' countryside type, with well-established socio-economic connectivity within the region (Perlín et al., 2010). Blatná SD is formed by a majority of non-peripheral municipalities (Kubeš and Kraft, 2011). Vimperk SD is situated in the mountainous landscape of the Sumava Mountains. This region is classified as an 'intensively utilised' rural region for leisure and tourism (Perlín et al., 2010). More than half of the municipalities here are classified as peripheral, especially those municipalities situated at the border with Bavaria (Kubeš and Kraft, 2011). Finally, Dačice SD is characterised as a 'problematic recreational countryside' type with overall low level of rural development (Perlín et al., 2010). About half of the municipalities in this SD are classified as peripheral, especially municipalities along the border with Upper Austria (Kubeš and Kraft, 2011). A summary of the four types of selected SDs is presented in Table 1.

\section{Data and methods}

The map of pre-1989 agricultural properties (Krejčí et al., 2019) was used as the main source of data input to accomplish the aims of our study. The pre-1989 agricultural premises were identified on topographic maps of Czechoslovakia at the scale of 1:25,000 from the late 1980s

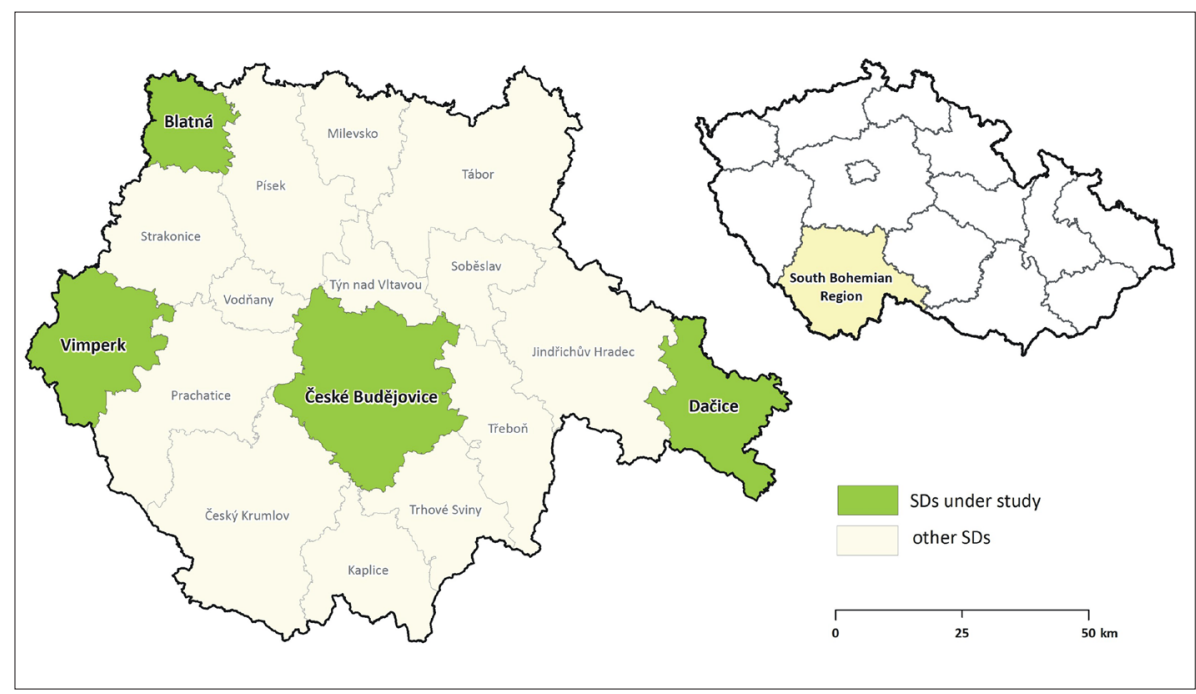

Fig. 2: Location of the four small districts selected in the South Bohemian Region Source: authors' compilation based on ArcČR 500 data 


\begin{tabular}{ll}
\hline Type of countryside & Selected SD \\
\hline Developed countryside surrounding upper-regional centre & České Budějovice \\
Developing countryside with well-established socio-economic connectivity within the region & Blatná \\
Intensively utilised rural region for leisure and tourism & Vimperk \\
Problematic recreational countryside type with overall low level of rural development & Dačice \\
\hline
\end{tabular}

Tab. 1: Summary of the types of countryside under study as represented by selected SDs in the South Bohemian Region. Source: After Perlín et al. (2010)

and the first half of the 1990s. Pre-1989 agricultural premises were areas labelled in the maps as agricultural area, cowsheds, pig farms, poultry farms, haysheds, horticultural fields and stud farms. Black and white prints of aerial images from the early 1990s were used to draw the borders of those premises and to find potential other pre1989 agricultural premises. Our four case study areas were sampled from this map.

Land-use data for the years 2004 and 2017 were gathered from free aerial images that cover the complete area of the Czech Republic. Two WMS services of The Czech Office for Surveying, Mapping and Cadastre (WMS - Ortophoto, WMS - Archival photo) were used. The images for 2004 were taken between 2003 and 2005; the images for 2017 were taken between 2016 and 2017. A final check of the aerial images was conducted using the panorama function that is freely accessible on the website application Mapy.cz. Thus, the categories of land-use for the years 2004 and 2017 are based on aerial images and are therefore relatively limited: listed below are the specific types of use in 2004 and 2017 of the pre-1989 agricultural premises:

- Agricultural utilisation (livestock breeding, storage of crop production and fodder, administration buildings, various water tanks, troughs and paved dung heaps, composting plants, biogas plants, agricultural storages, etc.), referred as "agri" in the graphs;

- Non-agricultural utilisation, utilisation for entrepreneurship but not agriculture (small craft production, industry, workhouses for repairing of agricultural mechanical machinery, scrapyards, nonagricultural storages, solar plants, sport grounds, etc.), referred as "non-agri" in the graphs;

- Housing, buildings used for permanent or recreational housing (buildings and their backgrounds), referred as "housing" in the graphs;

- Cultivated land (originally intensively cultivated land of agricultural farm that is currently ploughed, use as grazing or regularly mowed, including land that used be covered by buildings that were demolished), referred as "field" in the graphs; and

- No utilisation (abandoned premises, agricultural brownfields), referred as "brownfield" in the graphs.

For accuracy of the spatial data used, analyses of utilisation and changes in utilisation were conducted with a precision of $10 \times 10$ metres square. After the data preparation, statistical analyses were performed, so that individual hypotheses could be tested. Our hypotheses have been first re-defined as statistical null hypotheses and then tested. With respect to the nature of the analysed data (numbers of pixels of individual uses), chi-squared tests were used.

For testing Hypothesis 1 Pearson's chi-squared test for the fit of a distribution was employed. We were observing the distribution of areas of agricultural premises in the four studied SDs against a theoretical distribution of areas corresponding to acreage of those SDs. This type of Pearson's chi-squared test was also used for testing Hypothesis 2 in this case we tested the potential difference in the distribution of areas of enlarged agricultural premises in the four studied SDs against the even distribution corresponding to the acreage of those SDs (independently for 2004 and 2017). Pearson's chi-squared test for the fit of a distribution was also employed to test Hypothesis 3 the distribution of frequencies of types of uses in 2017 was tested against a theoretical distribution that was represented by the distribution of frequencies of types for 2004. For testing Hypothesis 4 and Hypothesis 6, a Pearson's chisquared test for statistical independence was conducted. Hypothesis 7 could not be tested by a chi-squared test as there were too many null cell entries in the pivot table.

To enable the testing of Hypothesis 5, two approaches were applied. First, Cohen's Kappa was calculated: this is a measure of agreement between two measured subjects that are often two classified maps (Viera and Garrett, 2005). It is similar to the Pearson correlation coefficient (Navrátilová et al., 2019). Based on this measure, the ratio of conformity for types of uses between two maps (two time horizons) of the same area, can be evaluated. A deeper view of this conformity, which is given by gains and losses of individual types of land-uses between 2004 and 2017, can be seen in a Mosaic plot, which is a graphical representation of multi-way contingency tables. It is commonly used in studies of land cover changes among land cover categories between two periods across several regions (Comber et al., 2016). It is a graph, in which its area is divided into rectangles having a proportional count of gains and losses for each land cover category in each region between two time periods (Navrátilová et al., 2019; SAS, 2017). The rectangles could be coloured - individual colours (in our case shades of red and green) represent the combination of variables being smaller (shades of red) or larger (shades of green) than an expected value under a model of proportionality and tested by standardised Pearson residuals (Comber et al., 2016). Hence, those rectangles with dark red and dark green colour are significant, because the main differences between real losses or gains and expected losses or gains are represented.

To enable a better reader orientation to the results, the data were graphically visualised either in proportional (percentage) scales or stated in absolute values. All calculations and the visualisation of the Mosaic plot were made by $\mathrm{R}$ software; other graphs were prepared in MS Excel.

\section{Results}

\subsection{Distribution of agricultural premises in $\mathbf{1 9 8 9}$}

Acreages of pre-1989 agricultural premises (the shares of area were specifically 19\% in Blatná SD, 44\% in České Budějovice SD, 23\% in Dačice SD, and 14\% in Vimperk SD) were not consistent with the acreages of particular SDs 
(chi-squared $=7,846.8, \mathrm{df}=3, \mathrm{p}<0.001$ ). In particular, Blatná SD had an acreage of pre-1989 agricultural premises extensively larger than expected according to the null model (150\%). It means that 50\% more agricultural premises (according to their acreage) could be found there than expected. A second region where specific details were found was Vimperk SD, where the acreage of agricultural premises in 1989 was just $56 \%$ of its theoretical extent (the acreage is equal to $70 \%$ of the acreage of the Blatná SD). In comparison, acreages of pre-1989 agricultural premises for both České Budějovice SD and Dačice SD are in line with the expected theoretical extent of the particular SDs.

\subsection{Increase of the extent of agricultural premises up to 2004 and in the period of 2004-2017}

There was an increase in the acreage of the original pre 1989 agricultural premises in the period 1989-2004, but it was only 207 ares (about $0.2 \%$ of the original acreage). In reality, one premise was extended in Ceské Budějovice SD and one in Dačice SD. There were no increases in Blatná SD and Vimperk SD: this does not necessarily mean that development did not happen there but it was rather limited to the borders of the pre-1989 agricultural premises. The difference is statistically significant (chi-squared $=117.46$, $\mathrm{df}=3, \mathrm{p}<0.001$ ). Up to 2017 an increase of the acreage of pre-1989 agricultural premises was detected in all four SDs. The detected overall increase is 5.88 ares, which is more than $6 \%$ of the original acreage of all pre-1989 agricultural premises (chi-squared $=5,319.64, \quad \mathrm{df}=3$, $\mathrm{p}<0.001$ ). Increases in the SDs of Vimperk (from 0 in 2004 to 162.9 in 2017), Dačice (from 92.7 to 319) and Blatná (from 0 to 87.8) are relatively comparable to one another, but a very large increase was detected in České Budějovice SD (from 112.8 in 2004 to 5,310.4 in 2017).

\subsection{Utilisation of pre-1989 agricultural premises in years 2004 and 2017}

More than one-quarter (28.2\%) of the pre-1989 agricultural premises had lost their agricultural use by 2004 and more than one-third (35.2\%) before 2017 (see Fig. 3). Almost one fifth (19.6\%) of pre-1989 agricultural premises were classified as brownfields in 2004. Quite surprisingly, a decrease of agricultural brownfields (to 15.2\%) was ascertained between 2004 and 2017. Non-agricultural use was detected for $7.4 \%$ of premises in 2004 and $15.2 \%$ in 2017. The areas of pre-1989 agricultural premises used for housing also increased between 2004 and 2017, as well as parts that were transformed into pastures, meadows and arable land. These changes are statistically highly significant (chisquared $=21,053.00, \mathrm{df}=4, \mathrm{p}<0.001$ ).

\subsection{Differences in land-use of pre-1989 agricultural premises in 2004 and 2017 among the four studied SDs}

Are there are any differences among the four studied regions in the use of pre-1989 agricultural premises separately for the years 2004 and 2017? We have found that the extent of individual types of re-uses varied significantly among these areas for both 2004 and 2017: year 2004: chisquared $=3,627.01, \mathrm{df}=12, \mathrm{p}<0.001 ;$ year 2017: chisquared $=3,123.68, \mathrm{df}=12, \mathrm{p}<0.001)$. In both studied time horizons, Dačice SD was identified as the most agricultural region: i.e. in this $\mathrm{SD}$, the acreage of agricultural premises with contemporary (2004 and 2017) agricultural uses had the largest share of the original extent of pre-1989 agricultural premises (see Figs. 4 and 5).

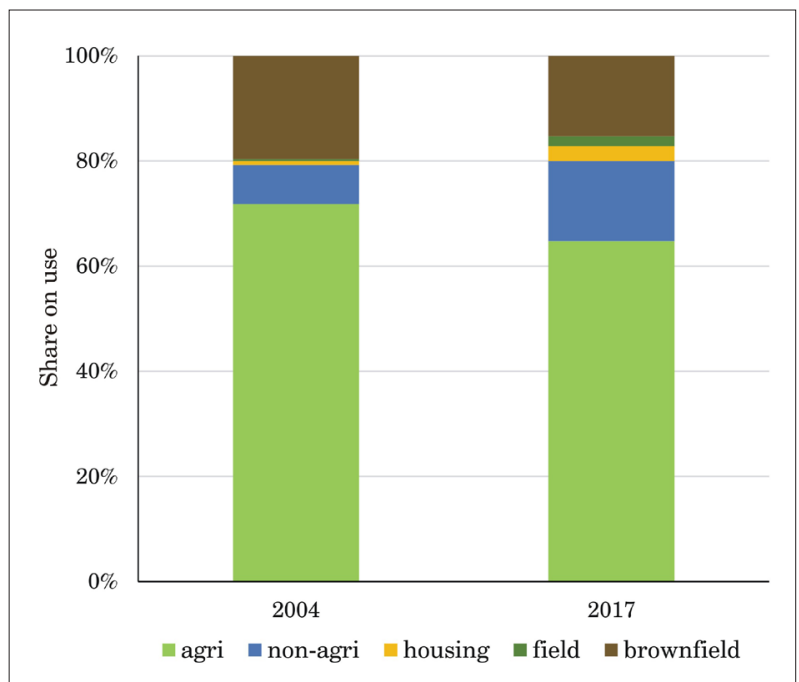

Fig. 3: The share of land-uses in 2004 and 2017 of pre1989 agricultural premises for all four $S D s$

Source: authors' calculations

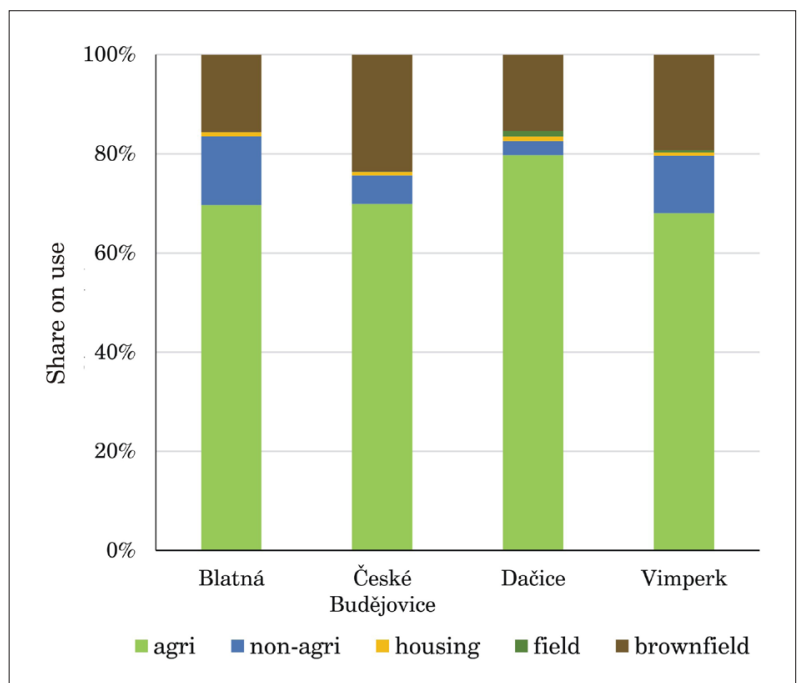

Fig. 4: The share of land-uses in 2004 on pre-1989 agricultural premises in the four study SDs Source: authors' calculations

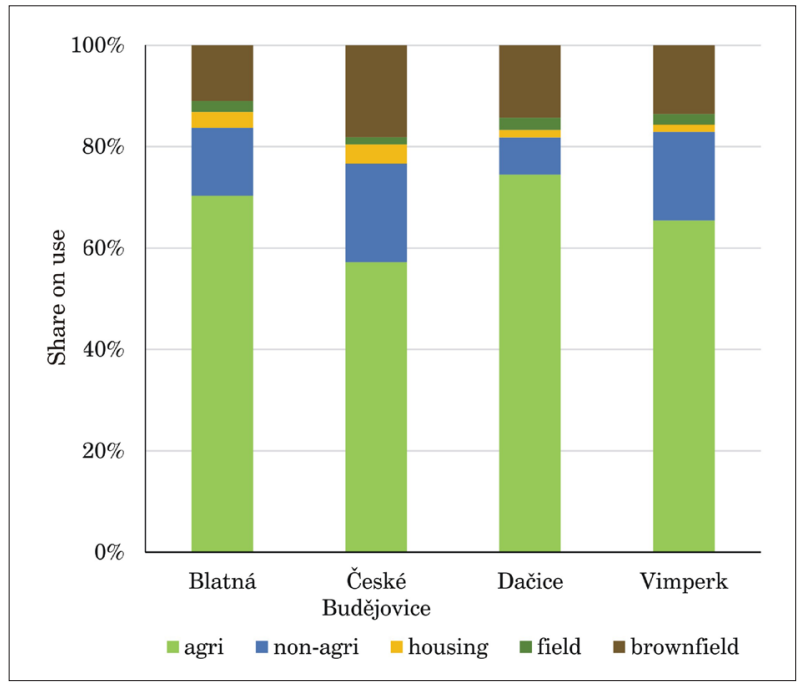

Fig. 5: The share of land-uses in 2017 on pre-1989 agricultural premises in the four study $S D$ s Source: authors' calculations 
In contrast, in all four areas the area of agricultural brownfields was higher in 2004 than in 2017. For all four regions, the development of non-agricultural uses increased by 2017 , but the most remarkable shift toward nonagricultural use can be found in the České Budějovice SD. A significant use for housing was detected in Blatná and České Budějovice SDs. With respect to the above-noted results, it is also interesting that only in Blatná SD was the level of agricultural use of pre-1989 agricultural premises the same in 2017 as in 2004.

\subsection{Changes of land-use of agricultural premises in 2004 compared to 2017}

Some conformity of the proportions between utilisations of pre-1989 agricultural premises in 2004 and 2017 was revealed by Cohen's Kappa (see Table 2). The results show that Blatná SD is the only region where a high stability of non-agricultural use in 2004 and 2017 was found ( $\mathrm{k}=0.88$ ): only minor changes in utilisation as 'non-agricultural' were recorded between 2004 and 2017. On the other hand, agricultural use seems to be relatively stable in all study SDs (all values are higher than 0.61). If we compare the stability of utilisations of all types of uses of pre-1989 agricultural premises in the four study SDs between 2004 and 2017, the most stable is Dačice SD; on the other hand, the most dynamic development in land utilisation was found in České Budějovice SD.
The stability of utilisations of pre-1989 agricultural premises might also be illustrated by a multi-way contingent table, where gains and losses of individual types of utilisations among the four study SDs are expressed in a Mosaic plot (see Fig. 6). The Mosaic plot shows losses and gains across all five types of uses of pre-1989 agricultural premises and the four SDs between 2004 and 2017. Almost all changes among the types of uses and regions are different from expected values, i.e. Standardised Pearson residuals are greater than +4.0 (dark green in the Mosaic plot) or smaller than - 4.0 (dark red in the Mosaic plot).

\subsection{Structure of the transition of agricultural brownfields: 2004-2017}

The areas of agricultural brownfields that were detected in 2004 and regenerated by 2017 significantly differs among individual regions (chi-squared $=2,440.18$, $\mathrm{df}=12$, $\mathrm{p}<0.001$ ). The most remarkable result of this analysis lies in differences between the two rather urban SDs (Blatná and České Budějovice). In both cases, the abundance of agricultural brownfields from 2004 was substantially eliminated by 2017. In Blatná SD, such development was caused by a significant renewal of agricultural activities in the region (40\% of agricultural brownfields from 2004 recorded agricultural use by 2017). On the other hand, in České Budějovice SD, the regeneration of agricultural brownfields was recorded for non-agricultural purposes.

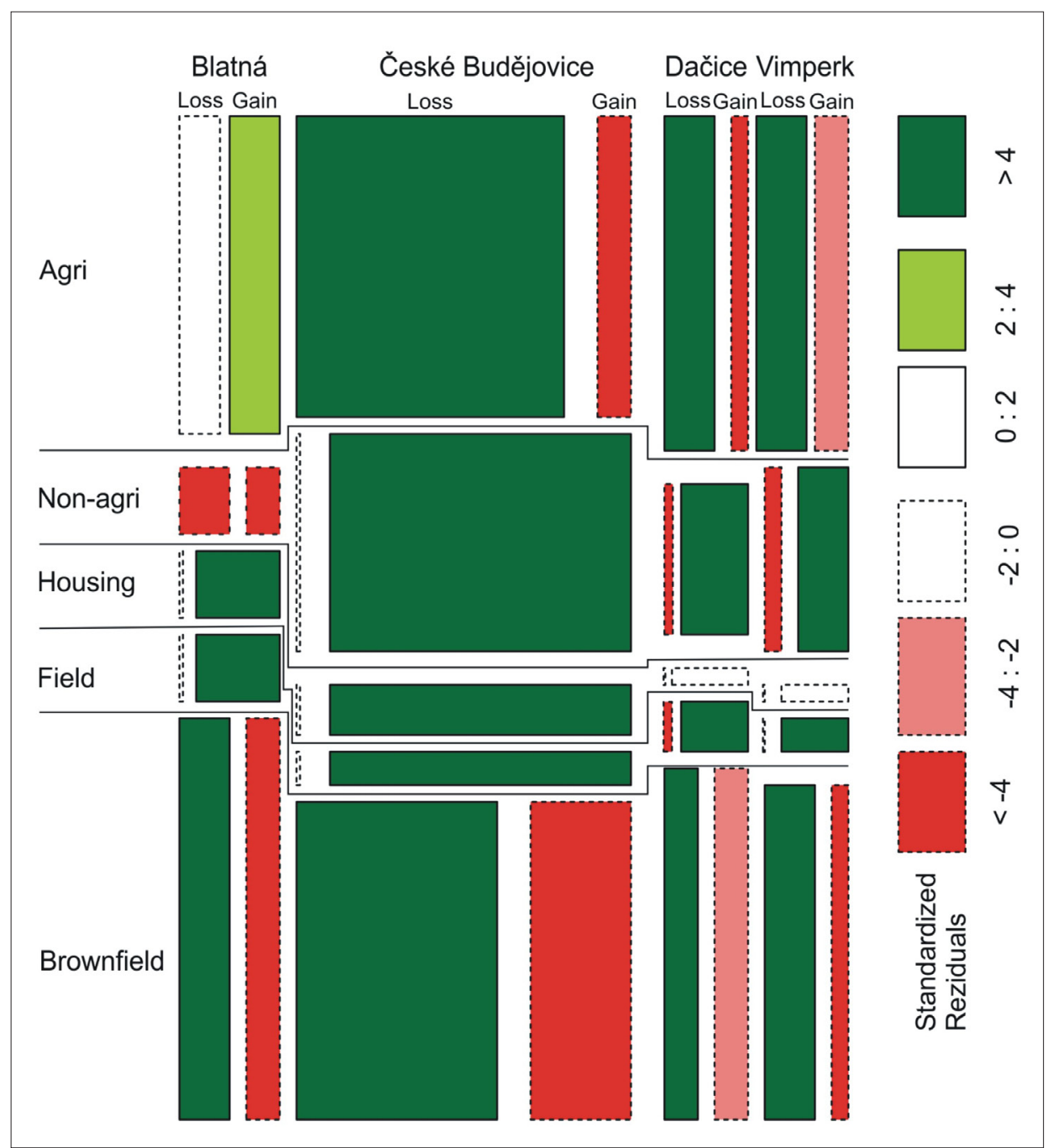

Fig. 6: Mosaic plot of the changes of all land-uses among all study SDs: 2004-2017

Source: authors' elaboration 


\begin{tabular}{lcccc}
\hline Land cover & Blatná & ČB & Dačice & Vimperk \\
\hline agri & 0.71 & 0.61 & 0.70 & 0.66 \\
brownfield & 0.33 & 0.40 & 0.56 & 0.44 \\
field & n.a. & 0.40 & 0.59 & 0.34 \\
housing & 0.43 & 0.32 & 0.73 & 0.62 \\
non-agri & 0.88 & 0.40 & 0.47 & 0.66 \\
\hline
\end{tabular}

Tab. 2: Cohen's Kappa for all studied types of land use and the four study SDs. Source: authors' calculations

In both SDs, we also discovered important agricultural brownfield regeneration for housing (in contrast to the other two SDs). In Dačice SD, 60\% of agricultural brownfields from 2004 were registered as agricultural brownfields in 2017 (see Fig. 7); in other SDs, their acreage was reduced by more than one half (in Blatná SD, it is one third compared to the situation in 2004).

\subsection{The structure of contemporary (2017) agricultural brownfields}

Employing the Mosaic plot (see Fig. 6), we identified the occurrence of new brownfields during this period. The evaluation of the last hypothesis should answer our effort to comprehend the origin of agricultural brownfields in various study regions (unfortunately, the hypothesis cannot be tested due to many null cell entries in the measured values). In all four studied SDs, contemporary agricultural brownfields (in 2017) are represented by more than half of the agricultural brownfields already existing in 2004 (see Fig. 8). This phenomenon is particularly important in the peripheral SDs of Dačice and Vimperk, where almost twothirds of the long-term agricultural brownfields are located. In Blatná SD, the occurrence of new brownfields is based on both agricultural and non-agricultural uses, whereas nonagricultural use does not generate any new brownfields in České Budějovice SD (in the period 2004-2017).

\section{Discussion}

There was no increase in the size of pre-1989 agricultural premises by 2004 , which might be interpreted as a result of minimal investments in agriculture in this period (Bičík

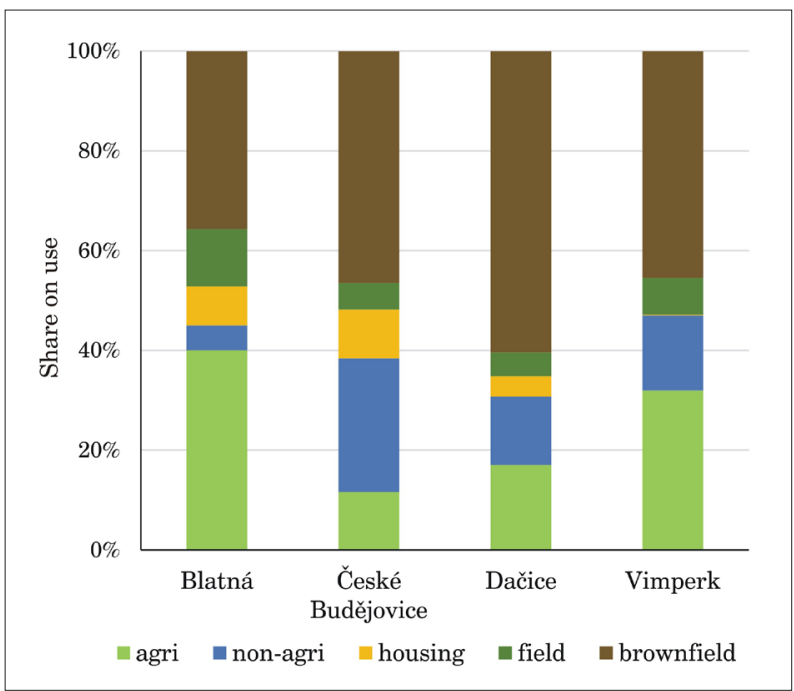

Fig. 7: The current use (in 2017) of agricultural brownfields existing in 2004

Source: authors' calculations and Jančák, 2005; Jančák and Götz, 1997) and difficulties in the adoption by Czech agriculture to "western" trends (Nešpor, 2006). On the other hand, expansion of agricultural activities is remarkable after 2004, both in the number of enlarged agricultural premises and their total acreage. Both indicators are closely linked to the effects of the subvention system connected to support of energy transition, i.e. the generation of renewable energies by agriculture (Chodkowska-Miszczuk et al., 2019; Martinát et al., 2016; Van der Horst et al., 2018). A major increase of acreage is linked to the installation of large-scale on-ground photovoltaic power plants (an increase of 5.114 areas, thus, for example, some $87 \%$ of new areas of agricultural premises in České Budějovice SD). This increase of non-agricultural use is most frequently seen at the expense of arable land immediately attached to the original agricultural premises (Klusáček et al., 2014). Only in two cases (covering a total acreage of 245 ares), have we found that pre-1989 agricultural premises were demolished and a photovoltaic power plant was developed. The remainder of these areas are covered by buildings connected to the development of biogas stations that were built in all four SDs (Van der Horst et al., 2018). The generation of biogas that was massively supported by the government between 2008 and 2012 (Martinát et al., 2016), is clearly behind the expansion of pre-1989 agricultural premises.

The tendency in the reduction of agricultural use of the pre-1989 agricultural premises that can be noted by 2004, continued also after that year. On the other hand, a significant decrease of the acreages of agricultural brownfields between 2004 and 2017 is detectable, as well as an increase of acreages of agricultural premises that were transformed into non-agricultural use and housing. This development documents an increase of investment inflows into agricultural premises after 2004 (Pelucha et al., 2017; Věžník et al., 2013), as redevelopments for housing need large construction works and frequently also demolitions (Věžník and Konečný, 2011).

These outlined tendencies vary between individual study SDs, however. For example, housing development as a new use of agricultural premises is primarily linked to highly urbanised areas, such as the surroundings of the City of České Budějovice, the regional capital. It is obvious

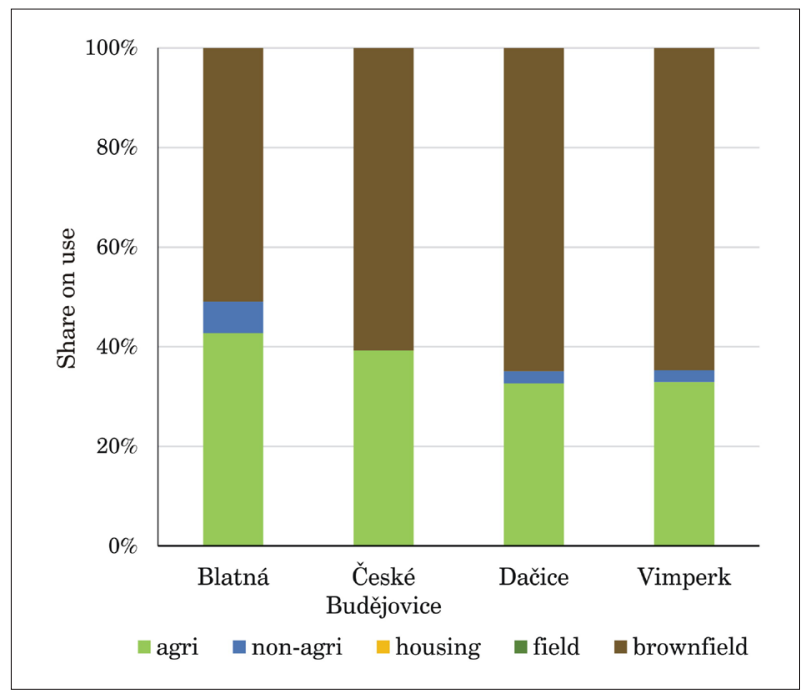

Fig. 8: The former use (in 2004) of brownfields identified in 2017.

Source: authors' calculations 
that housing and general property prices are significantly higher compared to other regions, which enables higher investments for the re-establishment of various properties into housing (Kubeš and Kraft, 2011; Popjaková and Blažek, 2015). The same factors account for investments into other non-agricultural uses. Thus, the existence of an agglomeration centre significantly affects possibilities for new uses of agricultural premises (Skála et al., 2013), which is a phenomenon that is not existing in the peripheries (Klusáček et al., 2013). On the other hand, Blatná SD presents a very interesting case as the redevelopment of agricultural premises into housing and non-agricultural use there is comparable to České Budějovice SD. Similarly, a high ratio of agricultural use of former agricultural premises was detected in both SDs. This is in contrast to the development in Dačice SD, where there is a high ratio of agricultural use, minimal housing use, a low level of non-agricultural use and a relatively high share of agricultural brownfields. The use of pre-1989 agricultural premises in Vimperk SD is somewhere between the two extreme examples mentioned above. This might be interpreted as a result of general development of three various peripheral regions (Kubeš and Kraft, 2011; Perlín et al., 2010).

České Budějovice SD appears to have the character of high dynamic changes in the structure of utilisation of agricultural premises between 2004 and 2017. This is primarily linked to very high losses of agricultural use in this period, and also to a high ratio of conversions into housing and non-agricultural activities. This SD might be described as a typical development region, where constant and dynamic changes in space use are typical as a result of competition among particular utilisations (Haggett, 2001), as well as suburbanisation processes in this area (Popjaková and Blažek, 2015).

Blatná SD is typified by high gains in both housing and non-agricultural use but at the same time, by the stability of agricultural use. At the same time, surprisingly, the higher level of renewal of agricultural use of agricultural premises (the lost agricultural function by 2004 and becoming agricultural brownfields that time) was detected here. Such results might indicate that the region around Blatná is an example of a rural territory that is traditionally based on agriculture but simultaneously is capable of experiencing economic growth (Perlín et al., 2010), as well as being able to perform expected functions (de Roest et al., 2018). From this point of view, Vimperk and Dačice SDs are in a worse situation as they are located along the state border (with Bavaria and Upper Austria, respectively), and both are formed by outer peripheries with all the development problems connected to such locations (Klufová and Šulista, 2018). At the same time, it is clear that in Dačice SD, changes in utilisation of pre 1989 agricultural premises between 2004 and 2017 were at a minimal level. This confirms the characteristics of it being the type of the countryside that is rather problematic with respect to development (Perlín et al., 2010).

For the utilisation of pre-1989 agricultural premises, the largest dynamic is connected to the rise in the numbers of agricultural brownfields or to the end of their life cycle (the occurrence of new use), as these fundamentally affect the character of rural settlement (Klusáček et al., 2013). What might be interpreted as surprisingly good news is that in three of the four SDs (except Dačice SD), there has been a decrease in the acreage of brownfields to less than one half (for the period 2004-2017). The most significant renewed utilisation of agricultural premises is detectable in Blatná SD, where the majority of premises experienced the return of agricultural functions and housing. This result also demonstrates the development potential of this SD as a functional rural region. In comparison, České Budějovice SD recorded the highest detected utilisation of pre-1989 agricultural premises for non-agricultural use. To emphasise, we have not detected any increase of new brownfields in the agricultural premises that were utilised for non-agricultural use in 2004, in the following years. These results might serve as confirmation of the assumed impacts of the upper-regional urban centre (the City of České Budějovice) on agricultural transition in its surroundings (Lazzarini, 2018).

A significant renewal of agricultural functions was also revealed in Vimperk SD. This SD is situated in a less favourable mountainous region, focusing mostly on extensive livestock breeding. A very large share of permanent grasslands farmed under organic farming status can also be found here (Zagata et al., 2019). The most problematic situation is evident in Dačice SD, where for more than 60\% of agricultural brownfields from 2004 no other new use has been found by 2017 . This result also illustrates the nondevelopmental position of the district.

We are persuaded that, in all studied regions, the most concerning factor for future development are long-term brownfields, as they form more than half of all brownfields (in peripheral SDs, it is almost two thirds). These sites are not only abandoned but, as a result of long-term desolation, they are also neglected. Therefore, redevelopment of structures within these long-term brownfields is not usually possible and demolitions remain as the only solution. On the other hand, a renewal of agricultural brownfields by means of demolitions usually makes the regeneration projects even more expensive, which makes such efforts even more difficult and challenging (Klusáček et al., 2018; Kunc et al., 2018; Limasset et al., 2018), especially for developmentally weak regions.

\section{Conclusions}

Changes in the utilisation of the pre-1989 agricultural premises of former cooperative farms and state farms in the last three decades are dynamic and significantly affected by their location. Many agricultural brownfields were recorded by 2004 and many sites had been utilised for non-agricultural purposes. After 2004, the acreage of agricultural brownfields has been reduced and new utilisations for housing and other non-agricultural activities significantly increased. The transitions in the land uses of pre-1989 agricultural premises are heavily influenced by the social and economic environs of particular sites. Firstly, it seems that proximity to an upper-regional centre is of crucial importance for decisions of how (and if) the site will be newly re-used. Secondly, the peripheral location of a site also affects the level and the selection of options for how particular agricultural premises are used. In these four case studies, the marginality of particular regions is increased by their location in the border regions of outer peripheries, where the probabilities of the presence of agricultural brownfields and of the long-term abandonment of agricultural premises is higher. The agricultural use of these premises has a particular importance here but its use for housing is rather limited. For a traditional developed countryside, we have found a typical low level of the share of long-term agricultural brownfields, but after 2004, the re-use of agricultural brownfields for agriculture was ascertained, which is complemented by use for housing. 
We believe that the results of our analyses complement existing knowledge on the spatial effects of agricultural transitions in various types of Czech rural regions after 1989. On the other hand, the limitations of this study have to be underlined, too. Four varying SDs in the South Bohemian Region were analysed, so that different development trajectories in the use of agricultural premises could be identified. Further research is needed so that the results of our analyses could be confirmed from other regions with varying social, economic and geographic conditions. Probably, researchers would obtain a very different picture if areas with good soil fertility were also analysed. In-depth probes on the types of regions of other CEE countries, where similar processes occurred in the last three decades, could be also useful for test purposes and to find out if our results possess general validity. In our opinion, the selection of time horizons for analyses (1989, 2004 and 2017) is justifiable, but surely, if other years were to be selected for analyses, more light could be shed on individual periods of the Czech and other CEE agricultural transitions.

\section{Acknowledgements}

This paper was completed with the financial support of project No. 19-23870S from the Czech Science Foundation titled: "Between de-agrisation and perforated development of rural space: The search for development patterns of postcommunist agricultural properties". We thank Jitka Bartrop for language revision of our text.

\section{References:}

BAŃSKI, J. (2008): Agriculture of Central Europe in the period of economic transformation. In: Bański, J., Bednarek, M. [eds.]: Contemporary Changes of Agriculture in East-Central Europe (pp. 7-20). Warsaw, Polish Geographical Society.

BIČÍK, I., JANČÁK, V. (2005): Transformační procesy v českém zemědělství po roce 1990. Praha, Univerzita Karlova.

BONFIGLIO, A., CAMAIONI, B., CODERONI, S., ESPOSTI, R., PAGLIACCI, F., SOTTE, F. (2017): Are rural regions prioritizing knowledge transfer and innovation? Evidence from Rural Development Policy expenditure across the EU space. Journal of Rural Studies, 53: 78-87.

CHODKOWSKA-MISZCZUK, J., MARTINÁT, S., COWELL, R. (2019): Community tensions, participation, and local development: Factors affecting the spatial embeddedness of anaerobic digestion in Poland and the Czech Republic. Energy Research \& Social Science, 55: 134-145.

COMBER, A., BALZTER, H., COLE, B., FISHER, P., JOHNSON, S. C. M., OGUTU, B. (2016): Methods to Quantify Regional Differences in Land Cover Change. Remote Sensing, 8(3): 19.

CZECHINVEST (2008): Základní statistické výsledky Vyhledávací studie brownfieldů. Praha, Ministerstvo průmyslu a obchodu.

CZECH STATISTICAL OFFICE (2018). Trh práce v ČR: časové řady 1993-2017 [online]. Available at: https://www.czso.cz/csu/czso/204r-k-odvetvi-cinnostizamestnanych-v-nh-iwyqej1k1f

DE ROEST, K., FERRARI, P., KNICKEL, K. (2018): Specialisation and economies of scale or diversification and economies of scope? Assessing different agricultural development pathways. Journal of Rural Studies, 59: 222-231.

DOUCHA, T., DIVILA, E. (2008): Changes in Czech agriculture in the years 1990-2005. In: Bański, J., Bednarek, M. [eds.]: Contemporary Changes of Agriculture in East-Central Europe (pp. 73-96). Warsaw, Polish Geographical Society.

FRANTÁL, B., GREER-WOOTTEN, B., KLUSÁČEK, P., KREJČ́́ T., KUNC, J., MARTINÁT, S. (2015): Exploring spatial patterns of urban brownfields regeneration: The case of Brno, Czech Republic. Cities, 44: 9-18.

HAGGETT, P. (2001): Geography. A Global Synthesis. Harlow, Prentice Hall.

HRABÁK, J., KONEČNÝ, O. (2018): Multifunctional agriculture as an integral part of rural development: Spatial concentration and distribution in Czechia. Norsk Geografisk Tidsskrift-Norwegian Journal of Geography, 72(5): 257-272.

ILLNER, M., ANDRLE, A. (1994): The regional aspectof post-communist transformation in the Czech Republic. Czech Sociological Review, 2(1): 107-127.

JANČÁK, V., GÖTZ, A. (1997): Územní diferenciace českého zemědělství a její vývoj. Praha, Univerzita Karlova.

KLAPKA, P., HALÁS, M., NETRDOVÁ, P., NOSEK, V. (2016): The efficiency of areal units in spatial analysis: Assessing the performance of functional and administrative regions. Moravian Geographical Reports, 24(2): 47-59.

KLUFOVÁ, R., ŠULISTA, M. (2018): Perceptions of Czech rural life by its inhabitants in connection to tourism. Deturope, 10(1): 5-32.

KLUSÁČEK, P., ALEXANDRESCU, F., OSMAN, R., MALÝ, J., KUNC, J., DVOŘÁK, P., FRANTÁL, B., HAVLÍČEK, M., KREJČ́I, T., MARTINÁT, S., SKOKANOVÁ, H., TROJAN, J. (2018): Good governance as a strategic choice in brownfield regeneration: Regional dynamics from the Czech Republic. Land Use Policy, 73: 29-39.

KLUSÁČEK, P., HAVLÍČEK, M., DVOŘÁK, P., KUNC, J., MARTINÁT, S., TONEV, P. (2014): From wasted land to megawatts: How to convert brownfields into solar power plants (the case of the Czech Republic). Acta Universitatis Agriculturae et Silviculturae Mendelianae Brunensis, 62(3): 517-528.

KLUSÁČEK, P., KREJČÍ, T., MARTINÁT, S., KUNC, J., OSMAN, R., FRANTÁL, B. (2013): Regeneration of agricultural brownfields in the Czech Republic - Case study of the South Moravian Region. Acta Universitatis Agriculturae et Silviculturae Mendelianae Brunensis, 61(2): 549-561.

KREJČÍ, T., NAVRÁTIL, J., MARTINÁT, S., PÍCHA, K., KLUSÁČEK, P., OSMAN, R., ŠKRABAL, J. (2019): Current use of former communist agricultural properties in South Bohemia. In: Klimová V., Žítek, V. [eds.]: $22^{\text {nd }}$ International Colloquium on Regional Sciences. Conference Proceedings (pp. 665-671). Brno, Masaryk University Press.

KUBEŠ, J., KRAFT, S. (2011): South Bohemian Peripheral Areas and Their Social-Population Stability. Sociologicky Casopis-Czech Sociological Review, 47(4): 805-829.

KUNC, J., TONEV, P., MARTINÁT, S., FRANTÁL, B., KLUSÁČEK, P., DVOŘÁK, Z., CHALOUPKOVÁ, M., JAŇUROVÁ, M., KRAJÍČKOVÁ, A., ŠILHÁN, Z. (2018): Industrial legacy towards brownfields: historical and 
current specifics, territorial differences (Czech Republic). Geographia Cassoviensis, 12(1): 76-91.

LAZZARINI, L. (2018): The role of planning in shaping better urban-rural relationships in Bristol City Region. Land Use Policy, 71: 311-319.

LIMASSET, E., PIZZOL, L., MERLY, C., GATCHETT, A. M., LE GUERN, C., MARTINÁT, S., KLUSÁČEK, P., BARTKE, S. (2018): Points of attention in designing tools for regional brownfield prioritization. Science of the Total Environment, 622: 997-1008.

LINDBLOOM, J. (2012). A far-reaching shift in argumentation: Parliamentary debates on (post-) socialist agricultural cooperatives in the 1990s. Eastern European Countryside, 18: 85-110.

MARTINÁT, S., NAVRÁTIL, J., DVOŘÁK, P., VAN DER HORST, D., KLUSÁČEK, P., KUNC, J., FRANTÁL, B. (2016): Where $\mathrm{AD}$ plants wildly grow: The spatiotemporal diffusion of agricultural biogas production in the Czech Republic. Renewable Energy, 95: 85-97.

MARTINÁT, S., NAVRÁTIL, J., PÍCHA, K., TUREČKOVÁ, K., KLUSÁČ́EK, P. (2017): Brownfield regeneration from the perspective of residents: Place circumstances versus character of respondents. DETUROPE, 9(2): 71-92.

NAVRÁTILOVÁ, J., HAVLÍČEK, M., NAVRÁTIL, J., FRAZIER, R. J. (2019): Land cover changes on temperate organic substrates over last 150years: evidence from the Czech Republic. Biologia, 74(4): 361-373.

NEŠPOR, Z. R. (2006): 'The son has ploughed', but a foreign son. Five case studies on transformation strategies in Czech agriculture after 1989. Sociologický časopisCzech Sociological Review, 42(6): 1171-1194.

PĚLUCHA, M., KVĚTOŇ, V., ŠAFR, K. (2017): Theory and reality of the EU's rural development policy application in the context of territorial cohesion perspective - The case of the Czech Republic in the long-term period of 2004-2013. Land Use Policy, 62: 13-28.

PERLÍN, R., KUČEROVÁ, S., KUČERA, Z. (2010): A Typology of Rural Space in Czechia according to its Potential for Development. Geografie, 115(2): 161-187.

POPJAKOVÁ, D., BLAŽEK, M. (2015): Verification of counterurbanisation processes: example of the České Budějovice region. Bulletin of Geography-SocioEconomic Series, 27: 153-169.
SAS (2017): Mosaic plot [online]. [cit. 15.06.2017]. Available at: http://www.jmp.com/support/help/Mosaic_Plot.shtml

SKÁLA, J., ČECHMÁNKOVÁ, J., VÁCHA, R., HORVÁTHOVÁ, V. (2013): Varios aspects of the genesis and perspectives on agricultural brownfields in the Czech Republic. Moravian Geographical Reports, 21(2): 46-55.

SVOBODOVÁ, H., VĚŽNÍK, A. (2009): To the problems of agricultural brownfields in the Czech Republic - Case study of the Vysocina region. Agricultural EconomicsZemedelská Ekonomika, 55(11): 550-556.

VAN DER HORST, D., MARTINÁT, S., NAVRÁTIL, J., DVOŘÁK, P., CHMIELOVÁ, P. (2018): What can the location of biogas plants tell us about agricultural change? A Case Study from the Czech Republic. DETUROPE, 10(1): 33-52.

VĚŽNÍK, A., BARTOŠOVÁ, L. (2004): Selected regional geographical differences of the Czech Republic agriculture, after the transformation processes. Agricultural Economics, 50(5): 207-216.

VĚŽNÍK, A., KONEČNÝ, O. (2011): Agriculture of the Czech Republic after accession to the EU: Regional differentiation. Moravian Geographical Reports, 19(1): 50-62.

VĚŽNÍK, A., KRÁL, M., SVOBODOVÁ, H. (2013): Agriculture of the Czech Republic in the $21^{\text {st }}$ century: From productivism to post-productivism. Quaestiones Geographicae, 32(4): 7-14.

VIERA, A. J., GARRETT, J. M. (2005): Understanding interobserver agreement: the kappa statistic. Family Medicine, 37(5): 360-363.

ZAGATA, L. (2012): Consumers' beliefs and behavioural intentions towards organic food. Evidence from the Czech Republic. Appetite, 59(1): 81-89.

ZAGATA, L., HRABÁK, J., LOŠŤÁK, M. (2019): Postsocialist transition as a driving force of the sustainable agriculture: a case study from the Czech Republic. Agroecology and Sustainable Food Systems, Online first. doi: $10.1080 / 21683565.2019 .1585400$

\section{Please cite this article as:}

NAVRÁTIL, J., MARTINÁT, S., KREJČÍ, T., PÍCHA, K., KLUSÁČEK, P., ŠKRABAL, J., OSMAN, R. (2019): The fate of socialist agricultural premises: To agricultural 'brownfields' and back again? Moravian Geographical Reports, 27(4): 207-216. Doi: 10.2478/mgr-2019-0016. 